metres and even several kilometres from the shore so that, whatever the meteorological conditions, the bacterial pollutants do not reach the shore alive.

Thus pollution on the beaches of the Côte d'Azur, which had reached an unpleasantly high level a few years ago, has considerably decreased. Similar improvements are being undertaken in other Mediterranean countries.

\section{New deal in French research?}

\section{from the staff of $\mathrm{La}$ Recherche}

For the first time since he came to power, M Giscard d'Estaing has invited a select committee on scientific research to the Elysée Palace. The report at the conclusion of this meeting set out in detail the government's scientific policy; in particular, it stressed that "the development and stabilisation of the French research efforts is becoming increasingly important, and France should rate among the leading countries with comparable resources in both the volume and quality of its research

". For the first time for many years, the government has thus confirmed its intention to give scientific research some degree of priority.

This political assurance is important insofar as the financing of research has been growing more and more difficult, because recent increases in research budgets have usually been lower than the average rates of growth for general equipment, and barely compensated for inflation. Although the GNP criterion may not necessarily be adequate in determining the research effort of a country, it is nevertheless significant that the portion of the GNP devoted to research in France has been consistently decreasing since 1967 , falling from $2.3 \%$ to $1.7 \%$ in the past seven years. This continuous diminution of the intensity of the research effort, along with serious problems of employment in science, has worried a large section of the scientific community, and the problem was brought to the public eye by two candidates for the presidency of the Republic in May 1974. M Giscard d'Estaing is now attempting to set matters straight in the projected budget, and so to turn away from the policy which he initiated when he was Minister of Finance.

The involvement of the Elysée is without doubt important politically, since it will give a major trump card to those responsible for scientific policy when the next budget discussions are being held--especially to the Minister for Industry and Research, M d'Ornano.

A meeting of ministers at the end of April will decide the main points of the 1976 budget and it will then become clear whether research is really to be recognised as a priority, and whether the increase in the finance available next year will permit real growth. And now, after the political assurances as to the principle of increased research efforts, and the speculation on the growth of the research budget, it remains to be seen whether French scientific policy will have new life breathed into it.

The first decisions announced after the meeting with the President already provide some useful indicators. On the level of the organisation and construction of research policy, important decisions are of three types. First, provision is made for the formation of executive groups to activate research in certain ministries. Their function would essentially be to coordinate and initiate scientific projects in ministerial departments. On the financial level, the enveloppe recherche which includes a large portion of non-scientific research, would be redefined. It will no doubt be extended in the future so as to cover certain other projects, such as the big civil aviation programmes and telecommunications research. This would allow better coordination of scientific policy. Provision is also made for the creation of a basis for intervention in the programme of the Délégation Générale à la Recherche Scientifique et Technique (DGRST). This measure could no doubt be most important for it would, in particular, allow the DGRST to instigate interdisciplinary re search projects on various subjects of great general interest.

The second series of measures announced concerns research personnel. It is first stated that science posts will be created "regularly and continuously". Measures will be taken to reabsorb the jobs of researchers without contracts, and to facilitate the mobility of staff, especially concentrating on better coherence of contracts and the devising of appropriate incentives.

The third type of decision aims to involve the scientist more in the responsibilities of scientific policy. It seems that there are divergent views on this. The government has in effect announced, on the one hand, that a committee presided over by M P. Aigrain (and including two academicians) would study reform of the Acadamy of Sciences and, on the other, that the role and composition of the Consultative Committee would be redefined. This choice can be interpreted as follows. A new, rejuvenated academy, would give the scientific community a forum where ideas could be aired, and a framework within which committees of cxperts could be formed to report on scientilic nroblems. The Aigrain com- mittee has already set to work to this end.

The Consultative Committee would be required to translate the wider socioeconomic needs of the whole country into the language of the practical objectives and means of scientific policy. On one matter the meeting with the President gave few precise details, that is, on policies relating to industrial research. Certainly, there is mention of the "economic assessment of the research effort" and of the importance of research to aid export growth, but it stays on the level of good intentions. Economic assessment of research was already on the cards in 1966, when the bill was passed creating the Agence Nationale de la Valorisation de la Recherche (ANVAR) on the model of the MRDC; it would be an exaggeration to say that no progress has been made on this problem in the past 10 years, but people have realised that the relation between science and innovation is far from being as simple as they thought.

It is on this problem of policy towards industrial research that the government document probably says least. A special committee under M R. Poignant will be handing in a report very soon on this question to the Minister for Industry and Research.

\section{Oceanography in Korea}

THE government of South Korea has recently been expanding its interest in science and technology, and nowhere is the interest more visible than in oceanography. Two years ago the Korean Ocean Research and Development Institute (KORDI) was established to coordinate the development of the country's marine resources and collaborate on an international scale. By 1977 the new Science City in Daejon will be housing KORDI and 16 other institutes in the process of being established; for the present KORDI is based in Seoul.

The growth of the institute depends much on international goodwill. The United Nations Development Programme has agreed to provide $\$ 800,000$ over three years, and bilateral assistance is being sought from Japan, European countries and the United States.

A staff of 63 is envisaged by 1977 and recruitment will be a major problem. Since many Koreans with the appropriate experience are living abroad, an extra effort has had to be made to attract them back; salaries are higher than those in comparable government departments, and modern housing is also being made available. $\square$ 